\title{
Loyalty, conscience and tense communion: Jonathan Edwards meets Martha Nussbaum
}

\author{
Joshua Hordern, Harris Manchester College, Oxford
}

\section{Affections and public reasoning}

In order to integrate public reasoning and religious liberty in modern democracies, Jeffrey Stout believes that 'religiously committed citizens' should argue for political conclusions by expressing 'their premises in as much depth and detail as they see fit when trading reasons with the rest of us on issues of concern to the body politic... [that is] on matters about which they care deeply.' He explains that if 'they do not have this opportunity, we will lose the chance to learn from, and to critically examine what they say.' 1 This approach contrasts with Rawls' 'public reason' in which, if a premise of Christianity belief in the God revealed in Jesus Christ - is not accepted by 'the rest of us', then the rational response to reasoning based on that premise should not be critical examination but peremptory dismissal. Stout finds this approach to public reasoning, including the version found in Rawls' amended versions, implausible, not least because it seems 'so contrary to the spirit of free expression that breathes life into democratic culture.'2

Stout's analysis presses the question of how religious contributions to democratic public reasoning can be learnt from and critically examined. I will argue that affectivity, as a dimension of moral thought by which people 'care deeply', has a quality which, if understood correctly, helps us to understand the 'tense communion' which exists between individuals and groups of varying comprehensive beliefs. It is through this communion, I suggest, that the dialectical, critical learning which Stout describes occurs.

Affectivity has been an under-explored feature of public reasoning. For example, Stout observes that what 'I can reasonably reject depends in part on [my] collateral commitments' which 'involve answers to religious questions and judgments about the relative importance of highly important values.' 3 The possible reasonableness of religious commitments is allowed for in the 'epistemic entitlement' which believers may have to those commitments. They have such entitlement to the extent that they are able to provide reasons for their beliefs, whether or not those beliefs can in turn be submitted

\footnotetext{
${ }^{1}$ Stout, J., Democracy and Tradition, Princeton University Press, 2004, 64

2 ibid. 68

3 ibid. 70
} 
successfully at some putative higher court of contractarian reasonableness. He argues persuasively that "if we link the term "reasonable" to epistemic entitlement and apply the term in a relatively permissive way, it will be very hard to make those who reject the contractarian project on epistemological grounds qualify as unreasonable.' ${ }^{4}$

However, what Stout overlooks is that exploring the values in which 'thick', sometimes religious, commitments subsist involves attention to their affective dimension. John Perry's account of the matter in terms of 'loyalty' suggests why correcting this omission is important. For Perry, if 'liberalism is to deal justly with the religious believers in its midst, it must comprehend and reckon with the substantive commitments, allegiances, and loyalties that constitute its citizens. 5 These loyalties concern obligations but loyalty itself 'is not a concrete duty. Loyalty binds me to an object, with the result that the object becomes a moral authority for me, and that creates concrete duties. Loyalty is also affective.' ${ }^{\prime}$ Perry's recognition of loyalty's affective dimension and religious citizens' struggle to reconcile their various loyalties presses the same question about public reasonableness as Stout, suggesting that Stout's term 'commitments' may be fruitfully interpreted via Perry's 'allegiances' or 'loyalties'. But Perry stops short of articulating what constitutes loyalty's binding power and just how affections relate to obligations, especially political obligations.

The claim here is that examining loyalty's affective dimension is necessary for understanding the epistemological significance of loyalty, including loyalty to God, in public reasoning. This builds upon Stout's belief that interpreting the role of commitments in public reasoning is 'a matter of epistemology'7 but applies it, in a way seemingly unanticipated by Stout, to how citizens interpret each other's affective valuations. This move will, I suggest, enable a more adequate grasp of how religious commitments play a role in political life than Stout has given.

The argument will first describe how cognitivist approaches to affections clarify questions about the epistemology of loyalty and commitment, including religious loyalties and commitments. This clarification will proceed through detailed exploration of two voices from North America, Jonathan Edwards and Martha Nussbaum. The relative merits and weaknesses of their differing interrelations of affections or emotions as regards loyalty's role in public reasoning will be assessed. This will lead to a consideration of the political significance of conscience and consensus. The claim will be that some discussions of 'conscience', such as Nussbaum's appropriation of Roger Williams, the seventeenth century North American Protestant theologian, share in the problems of the Rawlsian

\footnotetext{
4 ibid. 71; Stout depends on Wolterstorff's essay 'The Role of Religion in Decision and Discussion of Public Issues' in Audi, R. and Wolterstoff. N., Religion in the Public Square: The Place of Religious Convictions in Political Debate, Rowman and Littlefield, 1997

5 Perry, J., The Pretenses of Loyalty: Locke, Liberal Theory and American Political Theology, OUP, 2011, 22

${ }^{6}$ ibid. $42-43$

${ }^{7}$ Stout, J., Democracy and Tradition, 70
} 
notions of public reason and overlapping consensus by being inadequately attentive to the variety of religious concepts of conscience and, specifically, how those concepts relate to affectivity and loyalty. Talk of "religion" under-specifies the loyalty and conscience which characterise individuals and communities and with which liberalism(s) must reckon in forming a doctrine of freedom of religion. Conscience, it will be suggested, is actually basic to at least some religious thought about loyalty. Accordingly, the discussion turns to a particular case, Protestant Christianity, represented by Karl Barth's and Martin Luther's accounts of conscience, while signalling that similar analysis must be pursued in other religions especially Islam. The argument concludes by drawing on these rival accounts of conscience in developing a notion of 'tense communion' which more adequately describes political experience amidst comprehensive visions of reality than either Rawls' 'overlapping consensus' or Nigel Biggar's 'tense consensus'.

\section{Loyalties and affections}

Talk of political loyalties and affections may meet resistance. Kant's acceptance of the Stoic 'principle of apathy, namely that a wise man must never be in a state of affect, not even in compassion at the misfortune of his best friend' has led Kantian political philosophy largely to ignore or minimise politics' affective dimension. For Kant, affect generally brings impurity to moral thought. While, reverence (or respect) for law is a feeling... it is unique in that it is occasioned only by the presentation by reason of the pure practical law. This feeling is not the ground of morality, but is a consequence of our

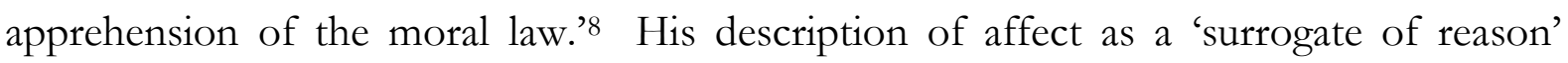
rather than a feature of reasoning suggests that loyalties, being non-rational in their affectivity, are inadmissible in public reasoning. ${ }^{9}$

Stout holds that Rawls' version of Kantian rationality is rightly supplanted by 'immanent criticism'10 in actual day-to-day democratic political discourse in a many-layered, backand-forth dialectic. But Kantian political theory may also be challenged epistemologically via cognitivist interpretations of emotions (affections) as constitutive features of all moral reasoning. Martha Nussbaum argues that emotions are object-directed, cognitive evaluations constituted by judgments which are often socially shared. They inform and are informed by culture and law, for good or ill, and may be commended or criticised. Therefore, to neglect conceptualisation of emotional forms of reasoning, such as shame

\footnotetext{
8 Hare, J., 'Kant, the Passions and the Structure of Moral Motivation', Faith and Philosophy, 28/1 (Jan. 2011), 54-70, 65-66.

${ }^{9}$ Kant, I., Anthropology from a Pragmatic Point of View, translated and edited by Louden, R., CUP, 2006, 152 (7:253).

10 Stout, J., Democracy and Tradition, 72-3; 'immanent critics...either try to show that their opponents' religious views are incoherent, or they try to argue from their opponents' religious premises to the conclusion that [a certain political] proposal is acceptable.' (69)
} 
and compassion, diminishes public discourse. ${ }^{11}$ For such emotions guide reasoning and bind people to objects in communal and, in principle, rationally defensible ways.

Stout's critique of Rawls' public reason is that it falsely suggests that we all 'argue in the same terms... a slightly adjusted version of the same terms dictated by his comprehensive secular liberalism.' 12 However, to uphold this complaint, one requires an epistemology which allows public assessment of the evaluative reasoning which constitutes commitments or loyalties. Stout does not provide this but cognitivist theories of emotion do.

Note that this implies that only some aspects of commitment or loyalty may be interpreted by overt appearances, such as wearing a burqa in public, banned in France in 2011. Such outwards forms do affect group loyalties but depend for their reasonableness on underlying values. An understanding of the burqa's role in public discourse must therefore engage with the moral and affective commitments of Muslim people.

A further example will help. Cognitivists think it reasonable for Citizen A to say 'rejoice not over $x$ but rejoice instead over $y$ ' and for Citizen B to disagree, giving reasons why such rejoicing is unreasonable, undemocratic, unjust, misinformed etc. In such an exchange, affections are evaluative features of moral reasoning open to criticism. For example, a citizen's hatred of other races and joy in their marginalisation may play a (malign) part in public reasoning, guiding both the tone and content of speech, forming obligations and energising actions. A loyalty, however reprehensible, is constituted when such affections are shared via the membership and leadership of a racist political organisation. Such affections become common judgments, uniting members within a shared authority structure and giving objects a significance which forms obligations. The loyalty thus constituted orients members towards their representative leadership who guide their deliberation toward action. Loyalty's affective dimension is thus basic to the group's perceived obligations to act in a racist manner. ${ }^{13}$

${ }^{11}$ Nussbaum, M., Upheavals of Thought: The Intelligence of Emotions, CUP, 2001; cf. Hordern, J., Political Affections: Civic Participation and Moral Theology, OUP, 2013 for theological engagement with Nussbaum's approach. For the cognitivist turn in 'emotion', cf. Dixon, T., From Passions to Emotions: The Creation of a Secular Psychological Category, CUP, 2003

${ }^{12}$ Stout, J., Democracy and Tradition, 76

${ }^{13}$ In response to a critic, (Gorringe, T., Review of Political Affections: Civic Participation and Moral Theology, Journal of Theological Studies, Advance Access published July 18, 2013 doi:10.1093/jts/flt088), it is important to underline that merely observing the political reality of how affectivity, authority and representation are interwoven guarantees notbing about the moral excellence or otherwise of any particular political representation or any particular hierarchically differentiated social order. Gorringe notes quite reasonably the duty critically to interrogate such structures. Indeed, there is always a complexly chequered epistemological relationship between 'world' and 'cosmos', between a particular (e.g. class-stratified, economically self-protective, ethnocentric) ordo amoris and the moral order created by God in which all members of humanity are equal participants (Hordern, J., Political Affections, 75-6). Gorringe's reaction, however, overlooks the critical vantage point which a Christological and eschatological fulfilment of the distinction between world and cosmos supplies over against the conservatism of e.g. Aristotle, Homer or 
Such loyal hatred and joy is perverse and should be publicly criticised because it involves an unreasonable evaluation which discriminates between people on grounds of race. Because of its cognitive-evaluative affectivity, it may be assessed by a polity through laws against racist words, actions and affections. For example, the UK Public Order Act 1986 makes it an offence to stir up racial hatred or to cause a reasonable person to fear for safety. ${ }^{14}$ Whereas Rawlsian epistemology minimises or ignores the way that affective evaluations of reality intelligibly constitute a political interest, recognition of loyalty's cognitive-evaluative, affective dimension entails that public reasoning explicitly incorporates loyalties, formed partly by shared affective evaluations, in public discourse, albeit sometimes through severe censure.

\section{Variations on an American theme: Jonathan Edwards meets Martha Nussbaum}

However, even if some loyalties are publicly recognised, whether in censure or in commendation, there remains the question of whether loyalties to God (or gods) are commitments which are unacceptable in public reasoning. Cavanagh notes the oftrepeated critique of religious affections, namely that religion is thought to have

a dangerous tendency to provoke and exacerbate violence wherever it is not domesticated and removed from public power by the secular state...religion has this lamentable tendency because it is an essentially non-rational impulse, a passion that frequently eludes or exceeds the attempts of reason to tame it. ${ }^{15}$

Cavanagh's observations combined with Stout's encouragement to religious believers prompt what follows, an 'immanent criticism' of one traditional Christian moral thinker alongside one contemporary political thinker aimed at clarifying just how loyalties can and do play a role in public reasoning. The latter, Nussbaum, a twenty-first century American adherent of Reform Judaism, mirrors the former, Jonathan Edwards, in his eighteenth century American Reformed Christian interest in affections. Despite this and Edwards' role in the pre-civil war colonial tradition which Nussbaum considers in her work on conscience (see below), they have not yet been put in sustained conversation. Nussbaum and Edwards both analyse emotions (or 'affections') but their doctrines,

English 'conservatives' (ibid. 95-6, 184, 215) and against pernicious forms of political leadership (cf. ibid. 143, 164, 198). As argued in Political Affections' third chapter, affective recognition is always operative, for good and ill, in political representation in all modern democracies through structures of participatory deliberation, mass communication, authority, leadership and election. It is fair to say that the first two chapters' critical apparatus vis-à-vis corrupt structures could have been more explicitly employed (e.g. in pp.165-72). Nonetheless, the inescapable implication for politics of the Christological-eschatological structuring of affection, authority, world and cosmos which I described, is that such representation, though necessary, must and will be judged by God in providential majesty and by people through political, often democratic processes.

${ }^{14}$ Cf. Kahan, D. \& Nussbaum, M., 'Two Conceptions of Emotion in Criminal Law', Columbia Law Review 96, 269-374

${ }^{15}$ Cavanagh, W., 'The Invention of Fanaticism', Modern Theology 27:2 April 2011, 226-237, 226 
including their accounts of conscience, differ on how and whether affective judgments and the loyalties they constitute, including loyalties to God, may inform public reasoning. They seem useful collocutors when battle lines are drawn in the USA and Europe between complexly multi-religious and multi-secular voices and when Edwards is himself experiencing a 'revival' amongst politically conservative Christians whom Perry identified as marginalised citizens ${ }^{16}$ and whom Nussbaum believes, in many cases, to be corrosive to American civic life. ${ }^{17}$ For the present purposes, their conversation will be focussed on the lacuna identified in Stout's critique of Rawls.

\section{Politics and affections in Jonathan Edwards}

The proposal that Nussbaum 'meet' Edwards immediately raises a question: since there are multiple interpretations of Edwards, which one will she meet? Edwards' 'sense of the heart', from which affections proceed, may seem well-suited to clarify loyalty's role in public reasoning. But some discount Edwards as a political theologian because he does not typically exhort church members to transform civil affairs. ${ }^{18}$ Robert Jenson's account of Edwards' 'Christian radicalism', ${ }^{19}$ while noting when Edwards does do this, describes him 'diametrically [dissenting] from standard liberalism as this was being born in his time', ${ }^{20}$ hardly a recipe for engaging with Stout's concern about Rawlsian public reasoning one might think.

On the other hand, Gerald McDermott claims that Edwards' theologically formed, social vision significantly shaped the colonies' socio-political outlook in the mid-eighteenth century. ${ }^{21}$ He argues that Edwards' social vision incorporated a metaphysical, aesthetic, relational ontology. McDermott highlights

the implications of his ontology for...temporality. Edwards would not brook... any retreat from a responsible and wholehearted commitment to action within history. For the Christian is driven by the propensive, relational, and enlarging nature of the divine being that has now infused his or her own disposition. ${ }^{22}$

\footnotetext{
${ }^{16}$ Perry, J., The Pretenses of Loyalty, 51-53, 159-63, where Perry discusses the Southern Baptist pastor, Henry Blackaby who depends on Edwards in works such as Fresh Encounter: God's Plan for Your Spiritual Awakening, B\&H Books, 2009. Cf. Stout, J., Democracy and Tradition, 76-7; Stout similarly argues for paying attention to Stanley Hauerwas' influence on everyday American church life.

${ }^{17}$ Nussbaum, M., Liberty of Conscience: in defense of America's tradition of religious equality, Basic Books, 2008, 45; Nussbaum relates how a Christian university lost its charitable status because of a policy of racial segregation, justified on theological grounds (139-40).

${ }^{18}$ For example, Alexis, G., 'Jonathan Edwards and the Theocratic ideal', Church History 35 (1966), 328-43

${ }^{19}$ Jenson, R., America's Theologian: A Recommendation of Jonathan Edwards, OUP, 1998, 7

20 ibid. 143

${ }^{21}$ McDermott, G., One Holy and Happy Society: The Public Theology of Jonathan Edwards, Penn State Press, 1992, 172-5

22 ibid. 100
} 
McDermott's claim is that Edwards' ontology must influence interpretation of his politics, complementing his infrequent political pronouncements. This uniting of Edwards' ontology and politics seems plausible in principle if not in every detail, ${ }^{23}$ cohering with Edwards' view that true virtue 'most essentially consists in benevolence to Being in general'24 which exhibits 'primary beauty' 25 and that secondary virtue has analogical implications for political institutions. ${ }^{26}$

McDermott's further claim is that because of this social ontology Edwards rejected 'social hierarchicalism' and supported 'an implicit egalitarianism based on the sense of the heart, a social model that had striking affinity to popular egalitarianism in the Revolutionary Age. ${ }^{27}$ The new spiritual sense of the heart, a new foundation - but not a new faculty - is laid down within Christians by God. ${ }^{28}$ From the sense of the heart proceed vigorous holy affections, the heart's inclined understandings, whereby a person has direct sensible perception of the beauty of the moral excellence of all things. ${ }^{29}$ Spiritual affections are moved precisely towards the consent and union of the believer, alongside other believers, with the beauty of Being in general and with God himself. ${ }^{30}$

For McDermott, such individual affections were central to Edwards' egalitarian ecclesiology. The sense of the heart gave access to God, affirming every believer's standing, whether male, female, black, white, rich or poor. By the sense of the heart, these individuals are gathered together to participate in Being and discern commitments and obligations under common ecclesial leadership. For McDermott, this pattern grounded Edward's egalitarian social vision, feeding a Republican political consciousness that led to the establishment of the United States of America.

Edwards' account, on this view, partially resembles the structure of loyalty outlined above, suggesting that his 'religious affections' may clarify the nature of loyalties and their role in public reasoning. But is this picture accurate and how does it bear on the question

${ }^{23}$ McDermott's observations rest partly (ibid. 97-100) on Sang Hyun Lee's contested interpretation of Edwards: that Edwards believed that God is a disposition, oriented towards the enlargement of his own Being (Lee, S.H., The Philosophical Theology of Jonathan Edwards, Princeton University Press, 1988). To my mind, Stephen Holmes has persuasively refuted Lee's exegesis, arguing that such an unorthodox statement cannot be derived from Edwards' writings. (Holmes, S., 'Does Jonathan Edwards Use a Dispositional Ontology? A Response to Sang Hyun Lee' in Jonathan Edwards: Philosophical Theologian, ed. Helm, P and Crisp, O, Ashgate, 2003, esp. 104-8.) Holmes' corrective still allows for a relational social ontology in creation towards which people are drawn, which is what is at stake politically.

${ }^{24}$ Edwards, J., The Nature of True Virtue, in The Works of Jonathan Edwards, Vol. 8: Ethical Writings, Ramsey

P. (ed.), Yale University Press, 1989, 540

25 ibid. 561

26 ibid. 568; cf. Hordern J., Political Affections, 166

27 McDermott, G., One Holy and Happy Society, 174; but see Hordern, J., Political Affections, 166 for how Edwards' social vision involves authoritative leadership.

${ }^{28}$ Edwards, J., Religious Affections, The Works of Jonathan Edwards, Vol. 2, Smith, J. (ed.), Yale University Press, 1959, 26

29 ibid. 271

${ }^{30}$ For a succinct exposition of this theme, see Daniel, S. H., 'Edwards as Philosopher', in Stein, S. (ed.), The Cambridge Companion to Jonathan Edwards, CUP, 2007 
of loyalty? Whether or not Edwards is open to McDermott's egalitarian reading depends on the weight one accords to the social ontology of Being in general. Certainly Edwards showed no great interest in 'democracy' or anything like it, as Jenson and Danaher argue; it is implausible to suggest that egalitarianism is the hallmark of Edwards' thought on civil society. ${ }^{31}$ But certainly too his emphasis on social consent and benevolence seems to favour a socially and ecclesially conscious awareness.

What is decisive - and what is at stake in penetrating loyalty's affective dimension - is the plausibility of Edwards' account of specifically religious affections. Edwards compared the sense of the heart concerning the beauty of divine things, including right behaviour, to the force of gravity by which a stone falls directly downwards to the ground. ${ }^{32}$ The passage of the stone 'shows the way to the centre of the earth' just as the sense of the heart 'teaches and guides a man in his behavior in the world.' Gravity and the sense of the heart discern the truth, whether physical or moral, more accurately than extensive scientific or moral reasoning can respectively attain. Edwards allows that the sense of the heart, although not constantly checking the particular rules of the Word of God, is yet generally subject to those rules and so 'must be tried by that, and a right reasoning upon it.'33 Against this more circumspect remark, Edwards describes Christian affections closing 'at once' with right action ${ }^{34}$ and holy affections, as expressions of 'divine taste', going straight to the 'true spiritual and holy beauty of actions'. ${ }^{35}$ Edwards 'was as skeptical of plebeian wisdom as any...But he was stubbornly confident that the sense of the heart would give supernatural insight and wisdom to any "common" person. 36 For Edwards, individuals, through the sense of the heart's affections, gain accurate access to moral wisdom. As Jenson says, this is a 'cognitive' account of affections although such cognition is of a peculiar kind, 'bearing the certainty of immediate perception.' ${ }^{37}$

This vision, I suggest, funds a Christian political psychology in tension with itself which clarifies the epistemology of loyalty by indicating what form that epistemology cannot take. On the one hand, on Edwards' social ontology, Christians are drawn outwards towards socio-political engagement, energised towards harmony with Being itself. On the other, there is an exalted epistemological confidence about the individual believer's

31 Danaher, W., Jonathan Edwards, Frances Hutcheson, and the Problems and Prospects of Civil Society', pp.179-196 in Storrar W. et al. (eds), A World for All?: Global Civil Society and Trinitarian Theology, Eerdmans, 2011

32 The image of the falling stone is Augustinian (Augustine, De Libero Arbitrio III.1) but, for Augustine, does not suggest the highly accurate epistemological orientation of the inclined Christian understanding which Edwards describes; O'Donovan, O., The Problem of Self-Love in St Augustine, Wipf and Stock, 2006, $19-21$.

33 ibid. 284; cf. ibid 285: 'a spiritual taste of soul, mightily helps the soul, in its reasonings on the Word of God, and in judging of the true meaning of its rules', removing prejudices and 'naturally' taking thoughts into the 'right channel'.

34 ibid. 281

35 ibid. 283

${ }^{36}$ McDermott, G., One Holy and Happy Society, 157

${ }^{37}$ Jenson, R., America's Theologian, 73; cf. 84 
affections. The sense of the heart may well underwrite an active sociality, whether egalitarian or hierarchical. However, on closer inspection, the nature of its affective perceptions renders the shared evaluations which constitute social loyalties and their criticism superfluous to determining moral obligations. Loyalty, I have suggested, concerns how shared evaluations constitute a common social or political interest which becomes authoritative through representative leadership. But if affections close immediately with right action, then discussion and representation is unnecessary. The moral discernment Edwards describes is insufficiently open to the reasoning about evaluations which form commitments and loyalties. If Edwards were right, Christians' ecclesial and political life would be characterised by unverifiable moral perception and inscrutable anti-political certainty. Any outwards movement towards political discussion would be threatened by peremptory, religious affections.

Whether or not Edwards may be interpreted in egalitarian, quasi-democratic fashion, which is doubtful, his account of religious affections entails that regenerate Christians' relations, amongst themselves and with unregenerate fellow citizens, will be characterised by affective evaluations which are not open to criticism. On the one hand, the radical distinction between regenerate and unregenerate affections makes affective political communion inconceivable. On the other, the belief in the benevolence of Christian affections renders such communion implausible; affections towards political affairs will normally be complex and, bearing in mind the typically unsatisfactory nature of political life, quite rightly more complex than pure benevolence. Edwards' religious affections being predisposed neither to require political discussion of value nor having the subtle variations such discussion requires, will therefore be open to the charge of 'pretence', the fate to which, in fact, many of Edwards' successors in North American Christianity have succumbed. 38

Edwards' conception of affectivity does not, therefore, assist in showing how loyalties, including loyalties to God, contribute to public reasoning but rather separates believers from epistemological interdependence with their fellow creatures, whether believers or not. The stake Christians might have in public reasoning - the realisation of relatively peaceful social union in accord with Being in general, albeit at the level of secondary virtue - is undermined by Edwards' over-realised affectivity. Therefore, one of Edwards' key doctrines, concerning religious affections, is simply incompatible with his social commitment and propensive ontology. ${ }^{39}$ That ontology, whereby loyalty to Jesus Christ entails social obligations, joined with a modified notion of affections, might yet be

\footnotetext{
${ }^{38}$ Cf. Perry, J., The Pretenses of Loyalty, 7-9

${ }^{39}$ For an analysis of how personal identity and forensic guilt fall apart in Edwards, see Helm, P., 'A Forensic Dilemma: John Locke and Jonathan Edwards on Personal Identity', in Jonathan Edwards: Philosophical Theologian, ed. Helm, P and Crisp, O. In a judgment similar to mine, Helm concludes that an 'element of [Edwards'] philosophical theology, the idea of divine immediacy and of successive re-creation of the creation, is...fundamentally at odds with another, his great Christian doctrine of original sin.' (58)
} 
politically useful, perhaps in association with his doctrine of excellency. ${ }^{40}$ Moreover, he believes that the unregenerate natural affections, such as a gratitude to God which is not 'first captivated' with Christ, may be critically assessed, classifying them below gracious affections. ${ }^{41}$ This is a plausible claim which might form part of a common grace interpretation of affections' role in loyalty.

However, the epistemology of Edwards' religious affections is not suited to form loyalties which can participate in intra-ecclesial or wider public reasoning. While Edwards himself commonly engaged in extensive argument, he describes the power of Christian affections to grasp moral truth at an implausibly high level, thereby minimising both the conceptual possibility of and the practical rationale for Christian loyalties' incorporation into public reasoning. Accordingly, contemporary conservative, American Christians, in their enthusiasm for political activity, should be as uneasy about Edwards' sense of the heart as they are about Rawlsian public reason.

\section{Emotions, conscience and consensus: Martha Nussbaum and loyalty}

The religious affectivity of “America's theologian" cannot address Stout's epistemological concerns about how the values of religious commitment contribute to public reasoning. Edwards' doctrine does not cast light on how Christian affections might be open to the criticism and learning required for democratic conversation. Nussbaum's cognitivist analysis of emotions explains Edwards' inadequacy in a way hitherto not understood. Her more measured description of emotions as culturally conditioned forms of judgment about the world, which may be assessed and critiqued, opens up the kind of learning and examination Stout seeks. Nussbaum's approach therefore represents a definite gain over Edwards. Her thesis shows how loyalties, in their affectivity and fully formed by cultural and religious context, may participate intelligibly in public reasoning.

However, Nussbaum is not such a good guide when it comes to 'conscience', a key feature of affectivity and religious liberty. In a discourse related to loyalty but, I shall suggest, in tension with her theory of emotion, she addresses

... a distinctive feature of the American tradition which is a personal, and highly emotional, sense of the preciousness and vulnerability of each person's conscience, that seat of imagination, emotion, thought and will through which each person seeks meaning in his or her own way... The free conscience, and the civil peace it requires, became the foundation of America's distinctive approach to religious liberty and equality. ${ }^{42}$

This notion of conscience aims to militate against 'a wall of separation' between religious and political affairs, since it would be 'weird and tyrannical to ask religious people to

\footnotetext{
40 Hordern, J., Political Affections, 120-30

${ }^{41}$ Edwards, J., Religious Affections, 246-7

42 Nussbaum, M., Liberty of Conscience, 37
} 
accept the idea that moral principles are utterly "separate" from their religious principles'. ${ }^{43}$ Instead, Nussbaum narrates an American theme stretching back to Roger Williams and forward to Rawls' Political Liberalism in which identities and forms of reasoning conditioned by comprehensive, even religious, commitments find accommodation. Failure to protect these identities damages people, she believes, in the depths of their humanity. For Nussbaum

Williams's romantic and deeply emotional picture of the conscience, as a lonely and vulnerable traveler in life's great wilderness, is the source of a distinctively American set of religious attitudes that have deep roots in many of us and... are attractive starting points for political thought. ${ }^{44}$

Whereas Edwards' affections, by which all Christian individuals gained ecclesial standing, were likened to stones falling by gravity, Nussbaum's cosmopolitan, Protestant-Stoic ${ }^{45}$ emotional conscience, upon which religious liberty is premised, is a wilderness wanderer, 'a general power of choice, the directing capacity of our lives'. ${ }^{46}$ She argues that this conscience should be woven together with Rawls' overlapping consensus by suggesting that

the idea of a moral and natural goodness which we can share while differing on ultimate religious ends...helps us think about our common life together much better than the unclear and at times misleading idea of separation. ${ }^{47}$

Whilst Nussbaum's Reformed Jewish adoption of Williams' notion of a shared natural goodness corresponds somewhat with a Christian account of the world's created goodness, her interrelation of overlapping consensus and conscience is inadequate to clarify the nature of religious loyalties for two reasons.

First, the notion of an overlapping consensus is in tension with Nussbaum's theory of emotions, which surprisingly plays no conceptual role in Liberty of Conscience. Emotions and the loyalties they constitute are culturally conditioned evaluations, necessarily stimulating democratic interchange about the value of goods which is forged in the profound differences there are between, in Edwards' language, regenerate and unregenerate and between the regenerate. But this is hard to reconcile with her acceptance of a Rawlsian overlapping consensus, especially her claim, contra Stout but with his fellow pragmatist Richard Rorty, ${ }^{48}$ that sharing in natural goodness will only be possible 'if we keep religious orthodoxy out of our common political life.' ${ }^{49}$ For any

\footnotetext{
43 ibid. 65

44 ibid. 70

45 ibid. $79-82$

46 ibid. 52

47 ibid. 65; cf. Upheavals of Thought, 401-2

${ }^{48}$ Cf. Stout, J., Democracy and Tradition, 85-91

${ }^{49}$ Nussbaum, M., Liberty of Conscience, 65
} 
consensus about goodness must substantially concern emotional perceptions about reality conditioned by people's culturally complex attitudes to the world. ${ }^{50}$ But deeply held religious beliefs are just such attitudes which will always colour public discourse. Therefore, it seems that, in an affective extension of Stout's criticism of Rawls' overoptimism about contractarian reasonableness, what constitutes shared moral and natural goodness will be significantly more contested than Nussbaum's elision of Williams and Rawls allows, routinely bringing strain to bear on any alleged consensus. In particular, the affections which articulate loyalty to the Christian God and gospel, being rooted in complex traditions of memory and practice, refuse to be domesticated into a uniform, neutral module. For such loyalty is conditioned by the eschatological, relational quality of ecclesial life in which any consensus worthy of the name is defined, in Edwards' terms, by consent to Being in general, a state of communion which will not be fully realised until the eschaton, in significant tension with every rival.

Therefore, while Nussbaum's rejection of 'the wall of separation' is psychologically astute, an overlapping consensus is inadequate not only to the theology characteristic both of eighteenth century and contemporary America but also to her own account of emotions. A hope that a Rawlsian module or 'natural goodness' will adequately attract common emotional reasoning in the form of loyalty, while more plausible than Edwards' account of religious affections, will be disappointed. For, as we shall see, the notion of 'overlapping consensus' misinterprets Christians' commitment to civil polity by failing to grasp their vocation to present and eschatological communion.

\section{Christian conscience and tense communion}

Perry recognises the issue by observing that 'Nussbaum largely takes for granted that all reasonable people share her view' of conscience but that her 'arguments will be unpersuasive' to those religious believers who do not. ${ }^{11}$ Perry's judgment identifies the second problem which is that Nussbaum's notion of conscience is unlikely to command widespread support among, for example, Muslims and Christians. As with the burqa ban so with many other questions of religious commitment: if politics is to take religious people's loyalties seriously, it must explore their affectivity as formed by the traditions which give those loyalties, and their overt demonstrations, coherence. ${ }^{52}$

\section{Christian conscience}

Conscience presses forward here as a key for thinking about loyalty because it combines thought about religious liberty with the affective dimension of loyalty which we have

\footnotetext{
${ }^{50}$ Nussbaum, M., Upheavals of Thought, 139-237

${ }^{51}$ Perry, J., The Pretenses of Loyalty, 196. Perry comments that 'even though Williams usually sounds more accommodating than Locke, this is only because he provides no theoretical basis; he simply asserts the inviolability of conscience.' (194)

${ }^{52}$ For Nussbaum's application of Williams' 'conscience' to banning the burqa, see 'Veiled Threats', New York Times, 11 th July 2010.
} 
been investigating - Nussbaum is right that conscience is 'highly emotional'. To return to Stout's initial challenge, liberty is something we 'care deeply' about in modern democracies; talk of conscience sheds light on its significance for Christian citizens and perhaps others.

To explore how this is so, Stout's encouragement that public reasoning attend to religious thought in detail may be followed by considering how accounts of Christian conscience relate to Nussbaum's proposal. Nussbaum's adoption of Williams' conscience as a wilderness wanderer is thrown into relief by Edwards. While the sense of the heart functions similarly to Williams' conscience inasmuch as it gives each individual protected standing, Edwards' conscience is not a self-directing wanderer but focusses precisely on the self's good or bad actions. The natural conscience, common to all, is 'a disposition in man to be uneasy in a consciousness of being inconsistent with himself...in his own actions. 53 This natural conscience's claim to affective and public significance is that it 'should approve and condemn the same things that are approved and condemned by a spiritual sense or virtuous taste', that is, by religious affections. ${ }^{54}$ For McDermott,

...both [regenerate and unregenerate] approve the same moral goals because of a common conscience that points uniformly to the same moral ends... [yielding] moral and epistemological grounds for the Christian working together with nonChristians in the public square in pursuit of the same moral ends. 55

The epistemological emphasis here seems to address Stout's concern. However, this judgment is only partially well-founded since Edwards' natural conscience is entangled in the difficulties of his religious affectivity which, as we have seen, is unsuitable for communal reasoning and loyalties, whether in ecclesial or wider civic settings. Rather than fostering intelligent, interdependent, affective communion with others who share the same civic space, Edwards' religious affections build up the 'wall of separation' which Nussbaum wants to break down. Disentangled from the spiritual sense, Edwards' conscience might yet inform shared public reasoning between Christians and other citizens, although, as I have argued elsewhere, even then it is problematic. ${ }^{56}$

Despite this, Edwards' thought at one point converges with a more politically plausible account of affections' epistemology. In eschatological mode, Edwards writes that the

love and joy of the saints on earth, is the beginning and dawning of the light, life, and blessedness of heaven, and is like their love and joy there; or rather, the same in nature, though not the same with it, or like to it, in degree and circumstances. ${ }^{57}$

\footnotetext{
53 Edwards, J., Nature of True Virtue, 589

54 ibid. 596

55 McDermott, G., One Holy and Happy Society, 106

56 Hordern, J., Political Affections, 179-81

${ }^{57}$ Edwards, J., Religious Affections, 113
} 
This notion of affectivity as a 'dawning' coincides with the account of affections I have developed elsewhere, namely that affections are the 'beginnings of understanding' - the 'half-light', as Jean-Yves Lacoste has said - rather than the bright light of Edwards' sense of the heart. If affections are the beginnings of understanding, a political practice of interrelating theologically formed and non-theologically formed loyalties is more plausible. For, if affections are half-light, then they both allow for and indeed require elucidation both in ecclesial settings and civic fora. By avoiding, for eschatological reasons, the over-realised religious epistemology of Edwards' divine and supernatural light, one gains insight into how loyalties are formed. ${ }^{58}$

For example, moving on from Edwards, an interrelation of eschatology with affections recalls and anticipates European Protestant notions of conscience, consideration of which both explains the limited appeal of Nussbaum's approach for religious believers, for whose civic participation she is concerned, and advances our investigation into loyalties, especially loyalties to God.

In an unrevised part of his corpus, Barth explains how conscience should not be conceived independently of Christ but rather to 'have a conscience is no more and no less than to have the Holy Spirit.' 59 By the Holy Spirit 'the voice of conscience is our own voice only inasmuch as in Christ our own future is present' so that, in conscience, 'our own voice is undoubtedly God's voice.' Through conscience, what 'I say to myself as a child of God I hear as a sinner saved by grace...I say it out of my future into my present'. ${ }^{60}$ Conscience is, therefore, 'the living and present message of the coming kingdom of God.' ${ }^{3}$ This conscience is not prospective in Aquinas' sense: the act of decision at the conclusion of a practical syllogism. Instead of the 'mad autonomism which has come to characterize the deeschatologised consciousness in both its modern and its Roman Catholic version', ${ }^{62}$ conscience is eschatological, summoning the individual to a future with Christ in the new heaven and new earth. Christ's summons, being the authority towards which Christian loyalty is oriented, authorises affective evaluations of the world now in light of the world to come. Conscience is affective for it involves an evaluative judgment (e.g. sorrow, hopeful joy or shame) on one's current condition in light of the future, simultaneously both condemnation and gracious vindication. Such conscience is basic to Christian liberty, since by it the believer experiences the justifying word of God and the freedom of the children of God. Such a conscience is distinct from modernity's inviolable individual conscience. ${ }^{63}$

\footnotetext{
${ }^{58}$ Hordern, J., Political Affections, 71-93; cf. Lacoste, J.-Y., 'Du phénomène de la valeur au discourse de la norme', in Lacoste, J.-Y., Le Monde et l'absence d'oeuvre et autres etudes, Presses Universitaires de France, 2000, $107-27$

${ }^{59}$ Barth, K., Ethics, tr. Bromiley, G., T\&T Clark, 1981, 477

60 ibid. 479-81

61 ibid. 487

62 ibid. 485

${ }^{63}$ Cf. Baylor, M.G., Action and Person: Conscience in Late Scholasticism and the Young Luther, Brill, 1977, 1-7
} 
Similarly, for Luther, Christian conscience involves an eschatological judgment on the person in light of both sin and the gospel of justification by faith. This departure from scholastic usage allowed 'Luther [to conceive] of the conscience as inherently an affective or emotional, as well as a cognitive phenomenon.' ${ }^{64}$ Conscience is an evaluative judgment on the person, in their thoughts, words and deeds. This conscience is free from condemnation but its freedom makes the believer restless, conscious of human vocation in God and human faithlessness, awakening awareness of social obligations now in light of the age to come. When intersubjectively shared by the Holy Spirit, this conscience forms the loyalties appropriate to communion with God and, as we shall see, the loyalties appropriate to creaturely communion with neighbours. Though personal first, a Christian conscience is inescapably directed towards the public. It is the internal forum which leads out to the public square.

\section{Tense communion}

This analysis of conscience brings us to the concept of 'tense communion', offered as an alternative to Rawls' 'overlapping consensus' and Nigel Biggar's 'tense consensus' and in response to Stout's worry that resentment of democratic life will define twenty-first century churches, reshaping the political landscape. ${ }^{65}$ Nussbaum recognises that any political conception needs to concern itself with citizens' motivations... [so as] not to impose impossible strains on human psychology'. ${ }^{66}$ The foregoing discussion suggests that a theologically formed Christian conscience cannot be replaced by a wildernesswanderer or reconciled with an overlapping consensus without doing violence to (many, at least) Protestant Christians' self-conceptions. In place of such de-eschatologised notions, Protestant Christians in eschatologically oriented conscience should establish and sustain not an overlapping consensus but a 'tense communion' of human loyalties with respect to the world's created goodness (akin to Nussbaum's 'natural goodness'), the goodness with which democratic discussion is typically concerned.

'Tense communion' is a Christian name for how people, subscribing to multiple eschatological visions or none, live together in a way whereby common, created social loyalties and obligations are discerned without occluding eschatological ones. For Christianity, identification in affective conscience with the civic identity of the New Jerusalem fosters a notion of loyalty more able than that offered by Roger Williams and Nussbaum to make sense of Stout's depiction of dialectical democratic conversation. The interrelation of present self with future self, mediated by Christ in conscience, forms a loyalty to Christ and the City of God, an allegiance whereby the self begins all understanding from affective participation in eschatological promise. This Christoecclesial loyalty involves believers discerning and realising a common vision of the present earth's future, under the authority of Christ, their victorious representative Lamb.

\footnotetext{
64 ibid. 209, cf. 209-72

65 See e.g. Stout, J., Democracy and Tradition, 104

${ }^{66}$ Nussbaum, M., Liberty of Conscience, 401-2
} 
This people, their loyalty substantially constituted by eschatologically toned affective understandings of creation, will be characterised by mutual epistemological interdependence with their non-Christian neighbours. This interdependent communion is necessary and possible because the affections of Christian conscience are constitutionally incomplete beginnings of understanding. For Barth, Luther and Edwards (in eschatological mode), affective judgments are constrained in conscience's epistemological humility by the distance between the church's present condition and the future promised in Christ. That distance means that Christian loyalties, constituted by conscience's affective evaluations, are half-light not bright light.

Accordingly, first, Christians may and must enter processes of political discernment with non-Christians and second, non-Christians are providentially equipped to question and assess the forms which Christian loyalty takes. Such creaturely communion is mediated through representative political institutions which form shared loyalties between people of all faiths and none. For Christianity, these institutions are themselves not free-standing but have an analogical relation to Christ's representation of his people, of humanity and creation as a whole. This double representative structure requires that political communion, though real and necessary, should be tense. Christian conscience is eschatologically oriented by the Holy Spirit, ensuring a permanent contest about the meaning of earthly life and goods, characterised by rival loyalties and affective judgments. Thus Christian conscience fosters both communion and tension.

Such 'tense communion', while similar in Augustinian spirit to Nigel Biggar's 'tense consensus', ${ }^{67}$ differs by suggesting a political life of both closer relational proximity and greater eschatological distance between believers and unbelievers than 'consensus' denotes. On the one hand, Biggar rightly notes that any consensus found in 'ethical agreement between Christians and others is not Rawlsian but Augustinian...not whole or stable but partial and provisional.' ${ }^{\prime} 8$ Just what this consensus consists of is not entirely clear. On the one hand, Biggar says that Christians and nonbelievers can 'share...ethical views' such as believing 'in human dignity' or 'in the virtue of justice'. Moreover, 'the Pastoral Epistles of the New Testament baptize lists of virtues conventional in Greek and Roman society.' ${ }^{69}$ However, Biggar also argues that the 'metanarrative hinterland'70 of ethics is decisive for what (for example) 'justice' means, inasmuch as, for Christianity at least, it must be ordered by love of the God revealed in Christ.

This makes one question whether 'consensus', even a tense one, can sustain the weight of describing the communicative interrelation of citizens from many different comprehensive, even eschatological visions. ${ }^{71}$ For 'tense communion', the common

\footnotetext{
${ }^{67}$ Biggar, N., Behaving in Public: How to Do Christian Ethics, Eerdmans, 2011, 42-3

68 ibid. 43

69 ibid. 27

70 ibid. 42

${ }^{71}$ Cf. Hordern, J., Political Affections, 253-61, 270-2
} 
creaturely participation of all citizens in social and political institutions is at the heart, incorporating the dynamic, historic dialectic Stout describes. Such communion may well include some partial 'consensus' at times; points of convergence are to be expected and valued. However, such consensus will normally be accompanied by misunderstanding and disagreement since it is situated in wider processes in which any agreement is relativized by differences of time, locality and, most strikingly in this context, the eschatological outlook of some citizens.

The publicity of political consensus' provisionality is maintained only if the promised eschatological communion with Christ remains the controlling feature of Christians' public reasoning. Indeed, this eschatological horizon protects the possibility of new forms of consensus emerging since it places strain on prior social agreements, thereby acting to break down entrenched, perverse loyalties, such as the racist or otherwise corrupted authority structures noted above.

Moreover, this tense communion, driven by a distinctively Protestant Christian conscience, presses further than Nussbaum and Roger Williams against the 'wall of separation' between so-called civic and religious realms. As Rowan Williams suggests, rather than 'trying to build up civic loyalty from nothing, a sympathetic state will build on the experience of co-operation and passionate concern for the common good that is nurtured in particular communities... by a religiously formed ethic'. ${ }^{72}$ The loyal affections which characterise this kind of Christian conscience are the fruit of such an ethic. Because formed by eschatology, they complexify civic commitments in polities are open to the examination and learning Stout describes, enrich debate and give political fellowship its due while allowing ultimate questions of human meaning to occasion political change.

\section{Conclusion}

Whether and how loyalty to Christ in conscience is paralleled in other religious loyalties would require comparison between and within, for example, Christianity and Islam. Further research is needed to explore how loyalties operate in various forms of Islam and relate to the public reasoning, critical examination and learning which will characterise mature, robust democracies that adjust to the inescapably tense communions of twentyfirst century, global political life. However, what is implausible, I submit, is that a single de-eschatologised Protestant notion of conscience such as Roger Williams' will do justice to the loyalties of a Muslim parisienne banned from wearing a burqa. ${ }^{73}$ Freedom of religion requires greater subtlety about the specifics of different religions and more complex, committed and tense communion than has so far been realised.

\footnotetext{
72 Williams, R., Faith in the Public Square, Bloomsbury Continuum, 2012, 128

${ }^{73}$ Cf. Winter, T., 'Muslim Loyalty and Belonging: Some Reflections on the Psycho-Social Background' in British Muslims: Loyalty and Belonging, The Islamic Foundation, 2003
} 
Stout's desire that democracies examine and learn from religious citizens' deep concerns has now been given a response shaped by Christian theology. Christian loyalties' affective evaluations are the beginnings of Christian public reasoning, entering public discussion about the common good open to mutual learning and critique. To begin with such affections is to begin where reasoning begins. The affective dimension of public reasoning, formed by diverse loyalties, acts as a creaturely access point for often robust deliberation concerning values and obligations in the tense communion in which polities will always stand, so long as they are inhabited by some who maintain eschatological loyalties to God. The prudent political approach is not to quell citizens' theologically formed loyalties but to foster civic participation by each person in representative institutions. Through 'critical participation in the institutions of a secular state', ${ }^{74}$ the affective evaluations of loyalties may be discussed, critiqued and sometimes censured. Tense communion within such institutions is the vocation of Christians, as they prepare, in fellowship with all creatures, for renewed communion in the new heaven and the new earth, the goal towards which they, in eschatological conscience, are summoned by Christ, who invites all people to draw near with faith.

${ }^{74}$ Williams, R., Faith in the Public Square, 41 